\title{
Protecting the right to defend Human Rights in Colombia: the Ríos Vivos Antioquia case
}

\author{
Protegiendo el derecho a defender los derechos humanos en \\ Colombia: el caso de Ríos Vivos Antioquia \\ Diana Marcela Rincón Henao \\ Global Campus of Human Rights \\ dianarinconh05@gmail.com
}

doi: http://dx.doi.org/10.18543/djhr.1911

Citation/Cómo citar: Rincón, Diana M. 2020. "Protecting the right to defend Human Rights in Colombia: the Ríos Vivos Antioquia case». Deusto Journal of Human Rights, No. 6: 239-263. doi: http://dx.doi.org/10.18543/djhr.1911.

Summary: Introduction. 1. Social movements and their defense of Human Rights. 1.1. Internationalization actions. 1.2. The struggle of social movements in Colombia. 2. The situation of Human Rights Defenders in Colombia. 3. Case study: the battle of Ríos Vivos Antioquia Movement against the Hidroituango dam. 3.1. Struggle strategies of RVAM. 3.2. The weak state response regarding the protection of Human Rights Defenders. 3.3. Internationalization as a protection bet. Conclusions. References.

\begin{abstract}
This paper focuses on the case of Ríos Vivos Antioquia, a social and environmental movement that fights against the construction of Hidroituango - the largest dam in Colombia- which has produced serious environmental and social impacts on the population surrounding the project. This article analyzes the internationalization of the struggle by this movement through different strategies aimed at defending the Human Rights of its community. For that purpose, this research uses documents produced by the movement and reports of some NGOs as well as interviews with members of RVAM and external collaborators to know their main strategies in some depth. This paper concludes that the strategies of internationalization used by this movement have resulted in the strengthening of the social struggle and the empowerment of the population in that region, which has been particularly affected by the violence in Colombia.
\end{abstract}

Keywords: Social movements, internationalization, human rights, human rights defenders, Ríos Vivos Antioquia Movement, Hidroituango. 
Resumen: Este trabajo se centra en el caso de Ríos Vivos Antioquia, un movimiento social y ambiental que lucha contra la construcción de Hidroituango - la represa más grande de Colombia - y que ha producido graves impactos ambientales y sociales en la población circundante al proyecto. Este artículo analiza la internacionalización de la lucha de este movimiento a través de diferentes estrategias dirigidas a defender los Derechos Humanos de su comunidad. Para ello, esta investigación utiliza documentos producidos por el movimiento e informes de algunas ONG, así como entrevistas con miembros de RVAM y colaboradores externos para conocer en profundidad las principales estrategias. Este trabajo concluye que las estrategias de internacionalización de este movimiento han tenido como resultado el fortalecimiento de la lucha social y el empoderamiento de la población de esa región, una población que ha sido particularmente afectada por la violencia en Colombia.

Palabras clave: Movimientos sociales, internacionalización, derechos humanos, defensores de derechos humanos, Movimiento Ríos Vivos Antioquia, Hidroituango. 


\section{Introduction}

A human rights defender can be any person or group of persons working to promote human rights, ranging from intergovernmental organizations based in the world's largest cities to individuals working within their local communities ${ }^{1}$. In Colombia, people who defend human rights individually or collectively face dangers and threats that can even endanger their lives; a situation that has worsened in recent years leading the country to be categorized as the bloodiest nation for Human Rights Defenders (HRDs) in 2019 with a total of 103 murders (Front Line Defenders, 2019).

Colombia is a country with a vast history of social movements that have revindicated the struggle for the defense of human rights. Trade union and student movements, as well as land and environmental defenders, have been the most active protagonists since the last century. However, stigmatization towards these people or groups who defend human rights is frighteningly high and most of them are pointed out as supporters of guerrilla groups, even though the Fuerzas Armadas Revolucionarias de Colombia (FARC), which was the oldest guerrilla worldwide, does no longer exist. These false accusations of relations between social leaders and illegal armed groups delegitimize the defense of human rights carried out by these people, thus undermining the social struggle in the country and putting at risk the lives of HRDs.

The signing of the peace process in 2016 with the FARC was a shaft of light for Colombians and for the rest of the world, since it marked the end of more than 50 years of war. Yet, since the signing of the peace agreement, the situation has worsened for those who are fighting to defend their lands and human rights. According to figures from the Colombian Ombudsman Office, at least 555 HRDs had been killed between 2016 and 2019 (Redacción Política 2020). In spite of this dramatic situation, the Colombian government has not shown enough commitment to protect the life of HRDs. What is worse, many times the current government has tried to modify the figures about the killings of social leaders to demonstrate a decrease in those rates.

Bearing in mind this grim reality, HRDs in Colombia have had to design their own strategies to protect themselves and to intensify their claims to defend their territory and human rights, and this is

1 See the UN Declaration on Human Rights Defenders. Accessed April 10, 2020

https://documents-dds-ny.un.org/doc/UNDOC/GEN/N99/770/89/PDF/N9977089. pdf?OpenElement 
the case of the Ríos Vivos Antioquia Movement (RVAM) which is a social movement that for over ten years has defended the rights of its community against the social and environmental effects that Hidroituango - the largest dam in Colombia- has caused in the population living near the project.

Though there are different studies on the Hidroituango case, the social movement that has directly faced this project has not been studied in depth. Hence, this article seeks to highlight the case of RVAM. The central hypothesis of this paper points out that RVAM has developed an internationalization strategy to highlight its struggle to protect its territory and the rights of its community, given the lack of attention from the Colombian state and the context of violence in which they carry out their work. To reach this point, the main strategies developed by RVAM to defend their human rights and the outcomes that these strategies have had in the last years were considered.

This research has a qualitative methodological approach with a case study that facilitates an investigation of a real-life contemporary phenomenon in its local context, with which it is possible to get a more comprehensive understanding of the current state of that situation. This investigation collected data from multiple sources aiming for triangulation as recommended by Wahyuni $(2012,72-73)$, in order to collect comprehensive, relevant information while also cross-checking its consistency to enhance the robustness of the findings.

Firstly, I reviewed each one of the publications on the RVAM website from January 2013 to May 2019. Then, I did a thematic analysis of these publications by identifying patterns in documents, reports, communications, press articles, and videos (over 30 resources). Every publication related to the movement's activities was analyzed and that allowed me to identify the list of the most recurrent claims and to know how RVAM has developed its main strategies for the internationalization of its movement.

Additionally, I conducted semi-structured interviews with five RVAM members: the president, vice president, and three active members of the group. They were chosen for being the ones with the greatest participation and recognition within the movement, and because of their work as HRDs. Likewise, I also sought information about external actors who have supported the movement such as NGO's and human rights lawyers. In total, four external supporters were interviewed, considering in all cases their contributions and work with RVAM. Among those interviewed, there is a lawyer from Colectivo de Abogados José Alvear Restrepo (CAJAR, in Spanish) a collective of lawyers recognized in Colombia for their work in the 
defense of human rights and who has supported RVAM by providing legal advice. Another interviewee was one member of the Swedish Movement for Reconciliation (SweFor) which is an organization that has supported reports on the consequences of the Hidroituango project on the affected communities. An anthropologist who has worked for years in that territory and who knows the dynamics around the dam was also interviewed. Finally, I spoke with a member of the Coordinación Colombia- Europa- Estados Unidos (CCEEU), an organization that has developed reports about human rights violations in that territory.

The documentary analysis together with the interviews allowed me to obtain a complete and detailed view of the activities and strategies of the movement from its first years to the present, which will be exposed in the ensuing pages and which show its process of internationalization. This research is divided as follows: after this introduction, the first part discusses the social movements and their defense of human rights. Then, the second part deals with the situation of HRDs in Colombia. The third section addresses the case study, and the last part includes the conclusions.

\section{Social movements and their defense of Human Rights}

For the Belgian sociologist Geoffrey Pleyers, today's social movements have a variety of nuances. These influence concrete policies, transform culture, daily life, produce knowledge, shape our society and open new scenarios. The 'Arab revolutions', the movements of 'Outraged' and 'Occupy' or movements that claimed for more democracy in Russia, Turkey, Brazil, Bulgaria, Senegal or Mexico are examples of these new expressions (Pleyers 2018).

According to Pleyers, the political subjectivities and the actors of today's social movements arise from the reciprocal articulation and fertilization between everyday life and political life, between the world of the internet and that of public squares, between social networks and coexistence in militant spaces. Thereby, to understand better contemporary social movements "we must overcome the separation between the 'virtual' world and 'real' politics. It is precisely in the hybridization between everyday life and politics, between virtual spaces and public squares, where new subjectivities arise in policies and new forms of citizenship, characteristics of contemporary social movements" (Pleyers 2018, 89). Today, social movements in their struggle against traditional development models propose other alternative models, 
cultural struggles (respect for their worldview and their way of seeing life) that are contrary to the capitalist model.

Thinking about social movements, not as mere objects of study but as political subjects that tell us a lot about our societies is one of the fundamental purposes of Pleyers' research. Current social movements not only make claims to defend their rights but also become political actors who make alternative proposals to transform their reality through legal resources, international advocacy, search for allies, and other resources with which they reach a higher impact with their claims; especially in the contexts of violence as is the case of most of the social movements in Latin America and Colombia.

And it is precisely that to examine the irruption of social actors and their articulation process in violent contexts, we start from the assumption that they are, in the most recent conjuncture, political actors in a precarious process of constitution or recently self-identified, and that they develop innovative forms of collective action (González 2006, 49).

Current social movements have incorporated new activities that have had a positive effect on claiming rights. They are movements that not only privilege direct action to mobilize or denounce, but also use legal resources and advocacy strategies.

\subsection{Internationalization actions}

Internationalization of social movements is strengthened thanks to the 'advocacy', which is an activity that promotes causes, principled ideas, norms, among others to produce influence and changes in decisions within political, economic, and social systems and institutions. Advocacy networks are significant transnationally and domestically, building new links among actors in civil societies, states, and international organizations. Transnational advocacy networks must be understood as political spaces, in which differently situated actors negotiate - formally or informally - the social, cultural and political meanings of their joint enterprise (Keck \& Sikkink 1998).

Advocacy strategies use the 'blame and shame' tactic that is the threat of international public opinion to coerce recalcitrant states to stop abuses. International advocacy has proved to be an effective strategy, which can be useful to support petitions before international bodies such as the Inter-American Commission on Human Rights of the Organization of American States, human rights treaty bodies of the United Nations (UN), the UN's special mechanisms; or to release 
reports abroad, sometimes in conjunction with international NGOs (Cavallaro \& Mohamedou 2005, 159). In addition, current cultural and technological changes have contributed to the growth of social movements' internationalization. New dynamics have been created with tools like Facebook and Twitter, which have become an important element in the different campaigns closing the distance between groups with similar claims and purposes around the world.

The internationalization of social movements in this research takes into account the concepts proposed by Margaret Keck and Kathryn Sikkink in their book 'Activist beyond borders', which describes the work of activists and social movements across national frontiers to influence in their own countries. Within social movement internationalization, the 'boomerang pattern' has a key role. Keck and Sikkink defined it as a method used by domestic groups to internationalize their struggle and echo back at the national level. When a government violates or refuses to recognize rights, individuals and domestic groups often have no resource within the domestic political or judicial arena. For that reason, they may seek international connections to express their concerns and even to protect their lives and a boomerang pattern of influence may occur that gives more pressure to the states from outside (Keck \& Sikkink 1998).

\subsubsection{Persuasion, socialization and pressure tactics}

Keck and Sikkink also point out the tactics used by social movements to reach their goals. These tactics are divided into four categories: information politics (refers to the production of information about the problems and claims produced by networks and which must be reliable and well documented); symbolic politics ( it is a way to "call upon symbols, actions, or stories that make sense of a situation for an audience that is frequently far away); leverage politics (networks seek leverage over more powerful actors to gain influence); and accountability politics (with this element, social movements look for government's answers and positions and they try to convert these statements into opportunities for accountability) (Keck \& Sikkink 1998, 16-24).

\subsection{The struggle of social movements in Colombia}

In the contexts of permanent violence, a possible decomposition of the political system associated not only with an extreme disaggregation 
of conflicts and a State in crisis are visible, but also the weight that the dispute of interests supposes in the International system. Under these conditions, it is necessary to consider the complex interaction of factors that create favorable conditions or restrictions on the deployment of collective action. Internal dimensions and international dynamics acquire special significance when it comes to specifying the variables that intervene in the identification of how and when a certain typology of collective actions occurs (González 2006, 54).

In Colombia, the collective actions of social movements are related to the consequences of the armed conflict, the development of a market economy that does not respond to the needs of a large part of the population, and the consolidation of a State that fails in the administration of justice, which has been penetrated by the allies of the armed actors and which, in general, admits few mechanisms of control and representation. The effects of these three processes result in the violation of civil and political rights and the denial of social rights for broad categories of people (Tanaka et al. 2010).

In this way, the Colombian anthropologist Arturo Escobar exposes how social movements are capable of "displaying alternative conceptions concerning women, nature, development, economy, democracy or citizenship that destabilize the dominant meanings" (Escobar 1999, 251). As HRDs challenge the boundaries of state oppression and violence, they invent creative tactics in order to counter attacks and respond to the political constraints imposed on their work. In some cases, HRDs use direct action and civil disobedience to further their goals, meanwhile, others use their vulnerability strategically, as a way of drawing attention to their issue" (Nah et al. 2013, 406).

For example, some movements have developed their own protection manual according to the specific context and problems. In addition, social movements defending human rights strengthen their networks with other groups at the national and international levels to share strategies that lead to more recognition of their work, a major level of protection, and an increased capacity to take collective actions. In Colombia, several social movements as RVAM have developed different strategies to defend their rights and protect their lives, given the violence and the lack of attention of the State to their petitions.

\section{The situation of Human Rights Defenders in Colombia}

The United Nations Declaration on Human Rights Defenders points out that a Human Right Defender is a person who, individually or with 
others, acts to promote or protect human rights and fundamental freedoms at the national and international level. Colombia adopted the definition of HRDs contained in the international doctrine of the United Nations and in the provisions of the Inter-American System, but the term 'social leader' is also used commonly in the country to refer to HRDs (this research uses both concepts).

Colombia has one of the most advanced normative frameworks in the region for the protection of HRDs. Since 1997, the country has had a program for HRDs who are at risk. Law 418 of 1997 ordered the Ministry of the Interior to put into operation a protection plan for people at risk because of the armed conflict and political violence. This mechanism has undergone several modifications, through successive decrees and resolutions, to adapt to HRDs demands, administrative requirements and decisions of the Colombian judicial system.

In addition, in 2011, the government created the 'Program for the prevention and protection of the right to life, freedom, integrity and security of individuals, groups and communities'. This program was implemented by the National Protection Unit (UNP in Spanish), which is attached to the Human Rights Office of the Ministry of the Interior. Its aim is to articulate, coordinate, and execute the provision of the protection service to those people determined by the National Government. This protection is for people in a situation of extraordinary or extreme risk because of the exercise of public office or other activities such as union leadership and human rights defense.

The UNP divided the protection measures into two categories: the soft measures, which include bulletproof vests, cell phones, and economic support; and hard measures, which include escorts and armored cars. However, social leaders mainly receive protection through soft measures that are, alone, not enough for their protection. These actions for protecting defenders carried out by UNP are not enough for several reasons: (1) it is based on a logic of material protection that forgets political action to protect HRDs; (2) there is no due prevention against aggressions and impunity of assaults against HRDs prevails; (3) there is a significant lack of knowledge of legislative changes and how to implement protection measures (especially by local and regional authorities); and (4) there are not enough resources and this delays requests for security measures (Eguren 2017, 25).

For its part, the current government adopted in 2018 the Action Plan for the Prevention and Protection of Human Rights Defenders, Social and Communal Leaders and Journalists (PAO in Spanish) (Ministerio de Interior de Colombia 2019). The government affirmed this is a strategy based on the identification, prevention of situations 
of risk, and with the articulated response of the different state entities to improve the human rights defenders' protection. However, Somos Defensores (the most important Colombian NGO in the field of HRDs) said that this program does not attack the roots of the problem: "This plan is insufficient because it does not consider the dismantling of armed groups in the territories, the structural fight against organized crime and the improvement of the well-being of the communities, which are situations that feed the cycle of violence" (Somos Defensores 2019, 60).

Somos Defensores also noted that "going back to stressing on physical protection, as the current Government does, will increase the demand for protection and therefore the budget will have to be increased. That means that there will be no substantive policies to avoid risk growth, and on the contrary, it will continue with the cruel trick of saving lives with vests, armored cars, escorts and telephones prolonging the problem, rather than solving it". (Somos Defensores 2019, 78).

Colombia has different mechanisms for HRDs' protection, but the State has failed in the proper implementation of these measures considering the context of violence in which the majority of social leaders live. Besides, the State has failed taking steps to attack the stigmatization which is one of the roots of this problem. Unfortunately when a social leader is threatened or killed, social processes and leadership are also killed. Hence, HRDs and social movements like RVAM have had to develop their own strategies to protect themselves and to ask for support from international organizations to defend their rights and lives.

\section{Case study: the battle of Ríos Vivos Antioquia Movement against the Hidroituango dam}

RVAM is a social and environmental movement composed of fourteen associations (about 1.200 families) of peasants, fishermen and barequeros ${ }^{2}$ who joined to fight against the construction of the largest dam in Colombia. According to the movement, its main objectives are the defense of its territory to stay in it, the defense of human

2 The term is used to refer to artisanal miners in the Cauca River region. The traditional artisanal mining method (barequeo) does not cause pollution to the environment and it is the main source of income for most people surrounding the Cauca River. 
rights, and the search for permanent solutions to the problems of its community.

Construction on the Hidroituango dam began in 2009. It was expected to generate 17 percent of the country's energy supply by 2018, but its construction was delayed and now the future of the project is uncertain. The main construction areas of the project are located on both banks of the Cauca River (the second largest river in Colombia) in the north of the department of Antioquia, $170 \mathrm{~km}$ by road to Medellin (the second-largest city in Colombia). The dam is being developed by the Antioquia Government and Public Companies of Medellín (EPM in Spanish), which is the largest company in that region and the most important service company in the country.

Although this project is primarily funded with national funds, international capital has been key for Hidroituango's start-up operations and this international investment has been highlighted by the Antioquia Government and EPM as a major support aspect for the project. They have tried to persuade the Colombians about the importance of the dam for the development of the region and the country, framing it as a symbol of 'entrepreneurship'. This rhetoric has become mainstream and thus, accepted by the majority of the population. Because of this, communities who oppose the project are accused of being 'enemies of development', causing the stigmatization of social groups that fight against the dam's construction (Ulloa \& Coronado 2016, 306), as is the case of RVAM.

RVAM has affirmed that it is undeniable that socio-political violence in the Hidroituango project zone has produced a big number of selective killings, forced disappearances, and thousands of displaced people. Therefore, RVAM has demanded official authorities to investigate the relationship between paramilitaries groups and companies in the region. Likewise, the movement has expressed that if the State does not recognize the influence and impact of the armed conflict in that territory; they are violating the rights of victims to justice and the guarantees of non-repetition.

In addition, violence and forced evictions were the reasons for over 400 members of RVAM to move to the city of Medellín in 2013. They lived in the Coliseum of Antioquia University for six months, claiming that the dam construction displaced them. However, in Colombia, forced displacement is only recognized when it is the result of the armed conflict according to Law 1448 of 2011. Hundreds of peasants, fishermen, and barequeros said they were victims of forced displacement because of the Hidroituango project, but unfortunately, they faced the lack of legislation on that subject. 
Likewise, violence in the Antioquia Department made it more difficult to set up the activities of RVAM because many people were afraid of the consequences of opposing the Hidroituango project. Although the first actions of RVAM started in 2009, it was not until August 2012 when the first big demonstration happened, according to the president of the movement, for whom this mobilization was a key moment for RVAM since people from different municipalities affected by the Hidroituango took part in it and compromised to fight against this project.

The movement went from having informal meetings to organizing a coordination team. In 2018, they established a board of directors to improve their daily organization. This body is made up of the president, vice president, two secretaries, treasurer, and two representatives who are in charge of carrying out operative tasks of the movement to have more control over their decisions and actions.

\subsection{Struggle strategies of RVAM}

This research found fourth main strategies used by RVAM in its battle against the Hidroituango project to denounce at the national and international level the human rights violations and environmental effects in that zone because of the dam construction. These strategies are: 1. Reporting and communicating human rights violations. 2. Asking the government for collective protection measures. 3. Claims to recover the bodies of forced disappearance victims. 4. Reporting and communicating environmental impacts.

The first strategy of RVAM is 'reporting and communicating human rights violations"; the movement has led this activity in the Hidroituango zone despite the risks and threats that they have faced. President of RVAM, Isabel Zuleta, has focused her speech on human rights violations to her community and she has broadcasted the social movement's work on diverse platforms. Likewise, RVAM has published in its website articles denouncing forced evictions cases, reports about human rights violations as well as documents and videos about strikes, protests, and mobilizations in different municipalities. Besides, the movement has reported the stigmatization and criminalization of some members, as in the case of its president, who has had inquiries for obstruction of track and retention of a public vehicle; violation of the right to work, and damages to third parties.

Regarding this strategy, RVAM also has participated in the InterAmerican Commission on Human Rights (IACHR) hearings with five 
interventions (between 2013 and 2018) on different topics representing cases of human rights violations in Colombia. Most of the panels which the movement has taken part in were about the relationship between extractive industries and threats faced by HRDs that opposed those projects. One of the key interventions of the movement in that IACHR space was on May 9, 2018, with the panel 'Measures for the protection of evidence in forced disappearance cases in Colombia', in which Zuleta reiterated that RVAM has led the pressure on the government to recover the bodies of forced disappearance victims in the Hidroituango zone.

Second strategy is 'asking the government for collective protection measures'. From the killing of the first member of the movement in 2013, RVAM started a battle against the Colombian state to claim the protection of its members not only through receiving individual security measures but also collective protection measures. For that reason, they presented in November 2017 the 'Prevention and protection plan for the Ríos Vivos Antioquia Movement. Risk scenarios, actions and preventive measures, protection, reparation, and guarantees of nonrepetition'.

The movement proposed fifty recommendations in that plan. Over $80 \%$ of these were related to political protection measures. For example, they recommended establishing public statements and rectifications from official institutions that would aim to decrease the attacks, stigmatization, and threats to RVAM members. About $20 \%$ of the recommendations involved material measures, affirming that their establishment implied a relatively low cost. Such as, the movement requested a training course on security and self-protection for two members of each of the fourteen associations that make up RVAM. Also, they demanded the installation of solar panels to improve communications in that region due to poor electrical connections in some rural zones.

In fact, Michel Forst, former UN Special Rapporteur on HRDs, said during his visit to Colombia in 2018 that the provision of non-material measures (political measures) is vital for guaranteeing a comprehensive State response to the risks faced by HRDs, their families and communities. For example, the development of public communications and social media campaigns to promote and recognize the important role of HRDs. Forst also pointed out that given that the highest risk situations for HRDs are concentrated in non-urban areas with greater State fragility and institutional weakness, the Colombian state should prioritize collective protection mechanisms. Likewise, he demanded to involve HRDs in the development, choice, implementation, and 
evaluation of strategies and tactics for their protection, affirming that the participation of them is a key factor in their security (OHCHR 2018).

Thanks to the claims and petitions of rights carried out by RVAM, the government created the Collective Protection Route. This program is addressed to groups and social communities politically determined from legal or social recognition, according to resolution 1085 of 2015 of the Ministry of Interior.

The third strategy is related to the 'claims to recover the bodies of forced disappearance victims'. According to RVAM, the 79-kilometer flooding of the Cauca River canyon because of the dam's construction means the irremediable loss of the bodies of forced disappearance victims. This situation could violate the rights of the families of the victims to the measures of truth, justice, and reparation, and for that reason, the movement has requested the Colombian state to guarantee the recovery of those bodies. The Prosecutor's Office said that they are investigating 502 cases of forced disappearance in that zone and also indicated that they have exhumed at least 159 bodies $^{3}$.

RVAM has developed symbolic events for this strategy as one performance carried out in 2017 with families of victims of forced disappearance. During that event, the families of the victims were symbolically buried, and they put plants on their graves with commemorative messages for their missing loved ones. The participants said that it was an exercise of reconciliation: "This was like healing the soul a bit, the performance helped me to join the movement more and was an opportunity to know deep about our problems. Planting means that we have roots in this land and that we resist leaving it. For example, I planted myself in the name of my two murdered brothers", said Estela Posada from RVAM. ${ }^{4}$

The president of RVAM pointed out that this strategy is very important to the barequeros who have a special cultural relationship with death. For that reason, they strive to recover the bodies of forced disappearance victims. "I believe that these feelings connect every people with mothers that seek their loved ones and due to this the campaign to recover the remains is related to deepest emotions for all people in this region", commented Zuleta 5 .

3 See Afectados por Hidroituango conmemoran a sus víctimas y piden rescatar su memoria. Accessed April 30, 2020

http://www.centrodememoriahistorica.gov.co/noticias/noticias-cmh/afectados-porhidroituango-conmemoran-a-sus-victimas-y-piden-rescatar-su-memoria

4 Telephone interview to Estela Posada, RVAM member, April 30, 2019

5 Telephone interview to Isabel Zuleta, president of RVAM, May 14, 2019 
The last strategy is related to 'reporting and communicating environmental impacts'. RVAM has defined itself as an environmental movement promoting the defense of its territory and economic, social, and cultural rights. They look for changing mining and energy politics in the country because, according to them, this is one of the main current reasons for displacement and banishment in Colombia. Hence, strategies of RVAM about environmental issues are related to its social claims. "For us, the defense of the Cauca river is nothing else than the struggle for life itself, for the right to stay in the territory and for the right to preserve our culture" (Torres 2019, 428).

The struggle of RVAM against the construction of the Hidroituango project is itself about the worldwide fight against the construction of dams. The movement has referred in its documents to the Report of World Commission on Dams (2020) that affirmed large dams generally have a range of extensive impacts on rivers, watersheds and aquatic ecosystems - these impacts are more negative than positive and, in many cases, have led to irreversible loss of species and ecosystems. Besides, the average lifespan of a large dam is about 35 years old, so these are just a short-term solution to solve a growing energy demand.

RVAM also drew attention to the report of the Environmental Impact Assessment (EIA) of the Hidroituango dam published in 2007. According to that report, almost 4,000 hectares of dry and humid tropical forest would be lost with the dam construction. Also, the project would contaminate and damage the quality of the waters, change the landscape, reduce vegetation cover, fragment and destroy habitats, increase the pressure for natural resources, and affect the migration of fish (Ortúzar et al. 2018, 12). The EIA reported 27 effects, only 3 positives, and 24 negatives. Despite serious environmental effects, Colombian official entities granted in 2009 the environmental licensing to developers of the project. According to RVAM, the EIA did not take into account collateral damage in the area, so the movement published an alternative report in 2016. This document named 'Call to the environmental reason in the ecosystem of the river Cauca River in the environment of the Hidroituango project', pointed out the importance of the tropical dry forest because of the number of endemic species inhabiting it.

Additionally, in 2018, RVAM presented its case against the Hidroituango dam before the Latin American Water Tribunal (LAWT) which is a non-judicial body looking for an alternative justice instance for the analysis and search of solutions to social and environmental conflicts related to water in Latin America. The idea of the movement was to expose the environmental damage caused by the Hidroituango 
project. In its verdict ${ }^{6}$, the LAWT blamed the Colombian State, EPM, and the Antioquia Government for the severe environmental, social, economic, and cultural damage that the Hidroituango project has produced to inhabitants of that zone. The jury recommended dismantling the Hidroituango dam and establishing a special program with the participation of the affected inhabitants. Besides, the jury claimed to EPM to support the recovery of the bodies of forced disappearance victims in the surrounding zone of the project.

Likewise, RVAM presented in 2018 an official complaint before the Independent Consultation and Investigation Mechanism (MICI) from the Inter-American Development Bank (IDB). MICI is an accountability body to improve the Bank's transparency and effectiveness. RVAM took its case before this mechanism to show the deficiencies and irregularities in the Hidroituango dam where the IDB is an investor. Moreover, the movement pointed out IDB didn't follow its evaluation requirements of environmental effects according to its operational policy.

\subsection{The weak state response regarding the protection of HRDs}

RVAM has denounced the increasing risks for the group in recent years due to its activities defending human rights. In September 2013, the first movement member was killed and two months later, the second. In 2018, two more members lost their lives, which has meant four RVAM leaders killed by July 2020. In addition, the movement members have been victims of threats, harassment, surveillance, smears and criminalization campaigns.

As a matter of fact, the problem of human rights defenders' stigmatization and criminalization were addressed by Michel Forst. He reported that criminalization of HRDs in the context of social protest is dangerous because they might be prosecuted for the crime of rebellion, conspiracy to commit a crime, terrorism, public road obstruction, attempted homicide and several other charges. Likewise, the UN former rapporteur expressed his concerns as environmental defenders have been particularly affected and criminalized for their participation in peaceful assemblies to defend the environment and to against extractive and business projects (OHCHR 2018).

6 See Veredicto del Tribunal Latinoamericano del Agua sobre el caso Hidroituango. Accessed March 10, 2020

https://riosvivoscolombia.org/wp-content/uploads/2018/10/Veredicto-TLA-casoHidroituango.pdf 
The situation with the RVAM case is more worrying since many of the people affected by the dam were previously displaced by the armed conflict. Even during the last two decades, the violence in that territory has increased. This area is used as a strategic corridor by illegal groups (guerrillas and paramilitaries) who seek the control of illegal crops and weapons trafficking (Gómez 2015, 73). According to CCEEU, in the Antioquia department paramilitaries have strengthened their presence and territorial control after the Farc demobilization which increased the risk to the population.

Oscar Zapata, represent of the CCEEU, pointed out the importance of denouncing the human rights violation in that territory to understand the realities and the context, as well as to draw attention to the HRDs' situation: "We have touched doors at the national and international level because we are concerned about the lack of political will to identify guilty actors, including the State, regarding threats to human rights defenders", said Zapata. ${ }^{7}$

At a more structural level, despite the existence of norms, institutions, programs, and measures to protect HRDs, the Colombian state has not responded adequately to the risks faced by them. Part of the reason for this is that the state still has a reactive, individual, and purely normative perception of protection. In other words, it does not act preventively and does not address the structural causes of violence against HRDs (Amnesty International 2020). For this reason, HRDs seek accountability in international spaces to draw more attention to these issues and like a way of protecting themselves.

\subsection{Internationalization as a protection bet}

The ability of networks to generate information quickly and accurately, and deploy it effectively, is their most valuable currency and the axis of their identity (Keck \& Sikkink 1998, 200). In this sense, RVAM has developed several strategies for reporting and communicating human rights violations, and they have assisted victims in taking their cases to courts and accountability institutions as they did with their participation in the IACHR hearings and the claims before the IDB.

Also, they used to leverage politics tactics to call for the support of external actors to put more pressure on the target institutions

7 Telephone interview to Oscar Zapata from CCEEU, April 29, 2019. 
because of the forced disappearance cases in that region. In addition, the movement often used the tactic of information politics through official complaints, petitions, communications, reports, among other publications, which showed human rights violations in its territory; meanwhile, symbolic politics was a tactic used by the movement mainly with mobilizations, strikes, and performances.

The use of the strategy of accountability politics was also exemplified after judicial institutions confirmed the need to implement collective protection measures in the country, where they exerted pressure on official entities to listen to their claims and their proposals. Likewise, RVAM used the tactics of accountability politics to denounce EPM for failures in the dam construction and its environmental effects.

According to the spokesperson of RVAM, they were looking for different spaces where they could be heard because of the refusal to have conversations with the local government and EPM. In that process, they took part in round tables about human rights violations issues and they got in touch with social organizations and human rights defenders' lawyers. Corporación Jurídica Libertad (CJL in Spanish) and the Colectivo de Abogados José Alvear Restrepo (CAJAR) are two national organizations that have supported the movement for several years. Both are organizations of lawyers that have helped RVAM with judicial advisory and juridical training courses. For example, the training of legal facilitators from CAJAR has been crucial for the movement, as many members who were illiterate and now even write documents for judicial processes.

Zuleta said a few years ago RVAM members were afraid to travel outside the country and denounce the human rights violations in that region but now they are more confident to talk about these problems in Colombia and abroad. These changes and evolutions have made RVAM's members key political actors in that zone: "There was a lot of fear because many of the leaders had never left the country, many of them had not traveled to Bogotá and some of them had not even visited Medellín. Taking that jump to go to another country was very frightening but the coordination team of the movement decided in 2017 that members should participate in abroad spaces. We have had an international agenda based on invitations to specific events, but also scheduled meetings. Last year, we participated with the CAJAR in a project of protecting environmental leaders and we developed advocacy strategies with the United Nations and civil society organizations". 8

8 Telephone interview to Isabel Zuleta, president of RVAM, May 14, 2019. 
The role of International NGOs has been key for the movement to create networks that legitimate its social struggle and to get a greater impact on national authorities. In this path, SweFor has widely supported the movement. This NGO has developed workshops of selfprotection for RVAM members and has accompanied them in meetings with official authorities. Likewise, SweFor supported the movement in the creation of a Prevention Plan in 2017 and it has helped RVAM with advocacy tours abroad.

SweFor coordinated the 'Human rights verification mission in municipalities of the Hidroituango project' accompanied by international organizations as Broederlijk Delen, OIDHACO, Mundubat among others. The verification mission was carried out between November 11 and 15, 2018 and its final report denounced the serious impacts of the Hidroituango project on people from this region.

The mission demanded the Colombian state and EPM to respect the right to truth, justice, reparation, and guarantees of non-repetition of the armed conflict victims who are being re-victimized because of the Hidroituango project. Likewise, the mission claimed integral compensation for all people affected by the dam, particularly for RVAM members and families of forced disappearance victims. Additionally, the verification mission recommended the international community to create a dialogue with RVAM, EPM, and the Colombian state to look for solutions to different problems in this zone arising from the dam construction. The mission also demanded that international investors, such as the IDB, respect human rights and to avoid negative impacts on the population with the projects that the bank finances. Finally, the report pointed out the need to present the Hidroituango case to the "UN Working Group on the issue of human rights and transnational corporations and other business enterprises".

According to Silvia Plana (2018), coordinator of the SweFor's report, these initiatives support the recognition of this social movement in other spaces and help them to stake their claims outside of the country: "We think international visibility is key as well as a face-toface accompaniment because these actions complement everything that can be done in political advocacy and communications at the international level". 9

Previously, in 2017, RVAM received in its territory a visit from representatives of the European Union delegation in Colombia who

9 Telephone interview to Silvia Plana: Swedish Movement for the Reconciliation (SweFor), April 30, 2019. 
aimed to obtain detailed information about the situation of human rights in that zone. Likewise, RVAM got the support of some European parliamentarians in form of a letter addressed to the Colombian government and EPM in which they asked for the respect of the human rights of the inhabitants in that zone due to the irregularities in the construction of the Hidroituango project. In addition, they demanded the government to strengthen the social struggle of this organization, and to respect the right of the families of forced disappearance victims to recover the bodies of their loved ones. In this sense, the president of RVAM also highlighted the international lobby, especially with the strategy of recovering the bodies of force disappeared victims, which is the strategy that has had the most development during the last two years.

The movement also has received the support of organizations like Amnesty International that has informed through communicates about the human rights violations in that zone and the risks for RVAM. In addition, in 2017, the Dublin Platform for Human Rights Defenders invited Isabel Zuleta to talk about the problems that affect her community. This space is a biennial event providing an opportunity for HRDs from almost every country in the world to gather and share strategies for advocacy and protection, build solidarity with colleagues around the world, and network with highlevel decision makers from governmental and intergovernmental bodies. "Thanks to all the complaints that we have made both nationally and internationally, we have managed to get more organizations and people to support our movement. We also like people to go to the territory so that they know firsthand what is happening there and the violation of human rights that we face", said Mauricio Madrigal, RVAM executive secretary. ${ }^{10}$

In this sense, several campaigns developed by the movement had more influence at the national level thanks to the international actors' help. RVAM leaders highlighted the importance of showing their struggle outside the country while also pointing out that international advocacy was useful because local authorities started to recognize the defense of their human rights. "For our movement, it is very important to reach international bodies because it is a voice of encouragement, a support for us to continue in what we do. We have a path to follow and we are being recognized not only in the region or at the national

10 Telephone interview to Mauricio Madrigal, RVAM executive secretary, April 30, 
level but also we are being visible internationally", pointed out Cecilia Muriel from RVAM. ${ }^{11}$

RVAM received the 'Organization of the Year award' from the National Human Rights Prize 2018 in Colombia, delivered by Diakonia and the Church of Sweden International Mission. The movement won that prize for its work related to environmental rights because RVAM focused on demanding responsibility from multinational mining companies regarding human rights and environmental legislation. Awards in the human rights area have one or more of the following purposes: protection (protective publicity for the winners); moral or psychological recognition; providing material support (such as money, lobbying, introduction to decision-makers, paid travel, access to project funding, training); and promotion of a specific cause or group (Thoolen 2013, 550).

Indeed, thanks to this award, one leader of RVAM participated last year in a European tour to raise awareness about the dangers and difficulties faced by people working for human rights in Colombia. Awareness tours offer opportunities for HRDs to spread the word about the dangers they face in their own voice. To that end, protection organizations facilitate meetings between activists and embassies, international organizations, and members of parliaments from different countries to increase their visibility and extend international support networks.

This research also examined how RVAM has changed during these ten years. The movement went from talking about the problems of the community because of the Hidroituango dam during informal meetings in parks and coffee shops to the creation of a coordination team charged to make decisions and develop strategies. Likewise, its repertoire of protest, its programs and its emotional values evolved. In the beginning, RVAM often carried out demonstrations and strikes. Later, they developed strategies to claim their rights in the judicial system and made complaints before national authorities. Now they are focusing on making claims - with the support of international networks - to look for accountability of the Colombian State, EPM and multinational corporations because of the violations of human rights of the Hidroituango project in that region.

When they made their claims in spaces such as the IACHR, the IDB, the European Parliament, among others, what they were looking for was recognition of their struggle at the international level so that it

11 Telephone interview to Cecilia Muriel from RVAM, May 2, 2019. 
became a support for their claims and it was a way to seek protection given the lack of attention from the Colombian state.

\section{Conclusions}

The evolution of the movement and its strategies shows the journey of RVAM's internationalization because as they developed different strategies to claim their rights, they also intended to draw the attention of international organizations to generate greater pressure on what was happening in the country regarding the Hidroituango project. The internationalization of RVAM began as something spontaneous, without much planning, as did most of the activities they carried out at the beginning of their struggle. However, as they advanced and managed to conquer other spaces, they began to propose the internationalization of the movement from different strategies that have developed in recent years.

Through the strategies exposed in this paper, RVAM mainly sought to disseminate all the information about the damages caused by the Hidroituango dam and the human rights violations taking place to get the attention at local, national, and international levels and then to establish the accountability of the involved actors. Meanwhile, the movement has become a key political actor in that zone not only because of its defense of human rights but also because of the fact that it is constantly creating alternative proposals to improve the living conditions of their community.

One of the most important outcomes of the RVAM is that its development of several social and environmental strategies led to its consolidation as an emerging social movement in Colombia. This achievement is particularly relevant since that region has been strongly affected by the armed conflict and thus the social struggle had been curtailed for years. Besides, many of RVAM's members were people who had never before been involved in planning strategies to claim their rights and, step by step, they have become active actors in decision making in an effort to defend their community.

It is also important to highlight the empowerment of women in this movement. They have developed networks with feminist organizations and they have led their own projects to strengthen their participation in their community. Besides, women leaders of RVAM are fighting to defend their rights, to improve their quality of life and conserve their autonomy. For them, barequeo is very important because it has given them economic independence and money to help their families. For that reason, they assured us that if this activity disappears it would 
affect their independence. Hence, they seek to protect this ancestral practice and develop other alternatives to earn money, such as making backpacks with environmental messages and producing coffee to be sold in different events in which they participate. The earnings are devoted mainly to the activities of the women association, but also to help women who are some families' sole breadwinners.

At the same time, RVAM members have strengthened the collective identity that allows them to feel proud of their achievements and they continue supporting people that have been re-victimized by the Hidroituango dam in the name of 'development'. Most of them have lost loved ones because of the armed conflict, so they claimed that this movement has become a new family; they describe it not only as a space for active participation in the region, but also as space for resilience.

Another important achievement of the movement was to draw attention to the need of recovering the bodies of forced disappearance missing victims in that region. RVAM has made great efforts to carry out this strategy and help the families of the victims. For that, they have taken advantage of every space in civil organizations at the national and international level to expose this issue and they have developed networks that have helped them to improve their claims on this topic.

The battle of RVAM against the Hidroituango project has been complex and dangerous. They not only defend the interests of their communities but also have to face threats and fight to protect their lives because of the dangers arising from working as HRDs. Despite its legal contention, protests, international advocacy and other efforts of the movement, the dam's construction continues in spite of its harmful environmental and social effects.

Today, the problem with the Hidroituango dam is not limited just to the effects caused by the construction itself, but the structural and technical problems of this project also increase the risk faced by the inhabitants, should the dam collapse. That is why RVAM's actions have greater value; they are fighting for the community in this area, who are suffering because the companies and the state - which should protect them- are violating their human rights. In this case, the responsibility of the State to protect its citizens seems to be displaced by the economic interests of this project.

This case study contributes to recognizing the work of RVAM and shows the importance of strengthening social movements that defend human rights around the world. The battles of these movements can both solve local disputes and provide answers to global issues. In this sense, RVAM's efforts are not only against the construction of the dam because of its negative effects, but they also challenge the 
current development model and propose alternatives that protect the environment, the territories, cultures, ways of life, and human rights.

Finally, this research also shows the urgency of implementing collective protection measures for social leaders in Colombia. With the Ríos Vivos Antioquia movement, in which most of its members exercise leadership and defense of human rights, implementing these measures is necessary so they can continue to claim their rights without fear of being killed, and without fear of threats and stigmatization campaigns. Likewise, the role of international organizations is fundamental to support social movements that defend human rights in countries where their governments ignore the claims, do not protect the HRDs, and do not recognize their pivotal work for the society. It is for this reason that the internationalization of their struggle is sometimes the only way that they find to protect themselves.

\section{References}

Amnesty International. 2020. Why do they want to kill us? Lack of safe space to defend human rights in Colombia. Accessed October 15, 2020 https:// www.amnesty.org/en/documents/amr23/3009/2020/en/

Cavallaro James \& Mohammad Mohamedou. 2005. «Public Enemy Number Two? Rising Crime and Human Rights Advocacy in Transitional Societies», Harvard Human Rights Journal 18: 139-165

Eguren, Luis E. 2017. Es tiempo ya: Políticas públicas eficaces para el derecho a defender los derechos humanos. Bruselas: Protection International and Cejil.

Escobar, Arturo. 1999. El final del salvaje: naturaleza, cultura y política en la antropología contemporánea. Bogotá: Cerec

Front Line Defenders. 2019. Global Analysis 2019. Accessed April 10, 2020. https://www.frontlinedefenders.org/sites/default/files/global_analysis_2019_ web.pdf

Gómez, Alejandra. 2015. Conflictos socio-ambientales alrededor de la hidroeléctrica Hidroituango, tesis de pregrado en sociología. Medellín: Universidad de Antioquia. Inédita.

González, Adriana. 2006. "Acción colectiva en contextos de violencia prolongada». Estudios Políticos 29, 9-60.

Keck, Margaret E. \& Kathryn Sikkink. 1998. Activists beyond Borders: Advocacy Networks in International Politics, New York: Cornell University Press.

Ministerio del Interior de Colombia. 2019. Plan de acción oportuna de prevención y protección para los defensores de derechos humanos, líderes sociales, comunales y periodistas. Accessed February 11, 2020. https:// www.mininterior.gov.co/sites/default/files/plan_de_accion_oportuna_de_ prevencion_y_proteccion_0.pdf

Nah Alice M., Karen Bennett, Danna Ingleton \& Jamen Savage. 2013. «A research agenda for the protection of Human Rights Defenders», The International Journal of Human Rights 5: 401-420, https://doi.org/10.1093/jhuman/hut026 
OHCHR. 2004. «Human Rights Defenders: Protecting the Right to Defend Human Rights», Fact Sheet 29 Accessed February 26, 2020 https://www.ohchr.org/ Documents/Publications/FactSheet29en.pdf

OHCHR. 2018. End of mission statement by the United Nations Special Rapporteur on the situation of human rights defenders, Michel Forst on his visit to Colombia, 20 November to 3 December 2018. Accessed March 4, 2020. https://www.ohchr.org/EN/NewsEvents/Pages/DisplayNews. aspx?NewsID=23960\&LangID=E

Ortúzar, Florencia, Astrid Puentes, Verónica Muriel \& Marcela Ribeiro. 2018. Detrás de las represas: Inversiones del BNDES en Belo Monte e Hidroituango Aprendizajes hacia un financiamiento responsable. Accessed 05 March, 2020. https://aida-americas.org/sites/default/files/publication/ Informe\%20Espanol_3.pdf

Plana, Silvia. 2018. Informe Misión de observación de la situación de derechos humanos y de seguridad de las comunidades en los municipios de influencia del Proyecto Hidroeléctrico Hidroltuango, Swefor en Colombia. Accessed February 15, 2020. https://riosvivoscolombia.org/wp-content/ uploads/2019/03/Informe-Misi\%C3\%B3n-Antioquia.pdf

Pleyers Geoffrey. 2018. Movimientos sociales en el siglo xxI: perspectivas y herramientas analíticas, Buenos Aires: Clacso.

Redacción Política. 2020. «Al menos 555 líderes sociales han sido asesinados entre 2016 y 2019: Defensoría del Pueblo», El Espectador, January 14. Accesed February 25, 2020. https://www.elespectador.com/noticias/politica/al-menos555-lideres-sociales-han-sido-asesinados-entre-2016-y-2019-defensoria-delpueblo-articulo-89982

Somos Defensores Program. 2019. Annual report: A Clockwork Orange, Bogotá: Somos Defensores.

Tanaka, Martin \& Francine Jácome. 2010. Desafíos de la gobernabilidad democrática. Reformas político-institucionales y movimientos sociales en la región Andina. Lima: INVESP.

Thoolen, Johannes. 2013. "Human Rights Awards for the Protection of Human Rights Defenders», Journal of Human Rights Practice 5: 548-555.

Torres, Astrid. 2019. Colombia Nunca Más: extractivismo-graves violaciones a los Derechos Humanos. Caso Hidroituango. 1990-2016, Medellín: Corporación Jurídica Libertad.

Ulloa Astrid \& Sergio Coronado. 2016. Extractivismos y posconflicto en Colombia: retos para la paz territorial. Bogotá: Universidad Nacional de Colombia.

Wahyuni, Dina. 2012. «The research design maze: understanding paradigms, cases, methods and methodologies», Journal of Applied Management Accounting Research 10(1): 69-80.

World Commission on dams. 2000. Dams and Development: A New Framework for Decision-Making, 2000. Accessed February, 15, 2020 https://www.internationalrivers.org/sites/default/files/attachedfiles/world_ commission_on_dams_final_report.pdf 


\section{Copyright}

Deusto Journal of Human Rights / Revista Deusto de Derechos Humanos is an Open Access journal; which means that it is free for full and immediate access, reading, search, download, distribution, and reuse in any medium only for non-commercial purposes and in accordance with any applicable copyright legislation, without prior permission from the copyright holder (University of Deusto) or the author; provided the original work and publication source are properly cited (Issue number, year, pages and DOI if applicable) and any changes to the original are clearly indicated. Any other use of its content in any medium or format, now known or developed in the future, requires prior written permission of the copyright holder.

\section{Derechos de autoría}

Deusto Journal of Human Rights / Revista Deusto de Derechos Humanos es una revista de Acceso Abierto; lo que significa que es de libre acceso en su integridad inmediatamente después de la publicación de cada número. Se permite su lectura, la búsqueda, descarga, distribución y reutilización en cualquier tipo de soporte sólo para fines no comerciales y según lo previsto por la ley; sin la previa autorización de la Editorial (Universidad de Deusto) o la persona autora, siempre que la obra original sea debidamente citada (número, año, páginas y DOI si procede) y cualquier cambio en el original esté claramente indicado. Cualquier otro uso de su contenido en cualquier medio o formato, ahora conocido o desarrollado en el futuro, requiere el permiso previo por escrito de la persona titular de los derechos de autoría. 